\title{
coo- $1760-6$
}

\author{
TECHNICAL PROGRESS REPORT \\ CONTRACT AT $(11-1)-1760$ \\ Washington University \\ St. Lou1s, M1ssour1
}

SUMMARY REPORT ON CYCLOCRON UTILIZATION, OPERATIONAL ACHIBVEMENTS, AND IMPRONEMENTS

DURING TWELVE MONTHS ENDING MAY 31, 1973

Submitted to the Atomic Energy Commission

Chicago Operations of fice

Chicago, Ilitnois

July 15, 1973

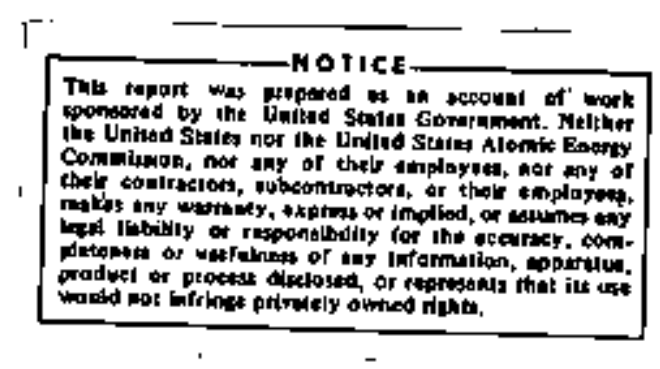




\section{DISCLAIMER}

This report was prepared as an account of work sponsored by an agency of the United States Government. Neither the United States Government nor any agency Thereot, nor any of their employees, makes any warranty, express or implied, or assumes any legal liability or responsibility for the accuracy, completeness, or usefulness of any information, apparatus, product, or process disclosed, or represents that its use would not infringe privately owned rights. Reference herein to any specific commercial product, process, or service by trade name, trademark, manufacturer, or otherwise does not necessarily constitute or imply its endorsement, recommendation, or favoring by the United States Government or any agency thereof. The views and opinions of authors expressed herein do not necessarlly state or reflect those of the United States Government or any agency thereof. 


\section{DISCLAIMER}

Portions of this document may be illegible in electronic image products. Images are produced from the best available original document. 


\section{INTRODUCTION}

The Chemistry Department at Washington University includes a substantial group of faculty members, post-doctoral research assoclates, and Ph.D.-candidate graduate students who are workIng in the research field of nuclear chemistry. Their specific Interests include studies of f1ssion processes, nuclear reactions, nuclear spectroscopy, chemical reaction processes via tracer atoms, oxidation-reduction reactions, etc. Most of their projects are funded through research contracts with the U. S. Atomic Energy Commission, but some are supported in other ways. The number of faculty involved is five, while the number of graduate students consistentiy stays in the neighborhood of 15 to 20. Over the past 7 years the research done by these persons has culminated in 11 doctoral theses and 93 published research papers.

The principal center for all of this research is the washIngton University Cyclotron Laboratory, located on the University's main campus immediately adjacent to the Nuclear Chemistry Laboratory. The Cyclotron Laboratory houses a 54-inch sector-focused cyclotron, a high-quality machine shop, an electronlcs shop, and an assortment of research space, augmenting that avallable in the Nuclear Chem1stry Laboratory next door and including a well-equipped, centralized data-acquisition station in the cyclotron control room. The Laboratory's staff currently includes 
flve full-time (or mearly full-time) engineers, technicians, and machinists, plus several persons part-time in various runctional capacities. The staff malntains and operates the accelerator, assistz users in utilizing 1t for their invegtigations, designs and construets a great deal of the specialized operation equipment which is needed, develops and perfects new modes of utilizing the accelerator and its peripheral facilities, and works continuously to improve the accelerator's performance characteristica and 1ts usefulness for its users. The machine shop and 1 ts two machinists, in addition to sharing in these normal staff functions, is also avallable for fabrication or research apparatus (as distingulshed from operating equipment) for cyclotron users who lack facilities of their own or who feel that the Cyclotron Iaboratory shop offers special advantages In experience and expertise. The engineers of the staff devote considerable time and effort to the design and development of this kind of apparatus, in addition to more directiy cyclotronrelated functions.

Funding for the Cyclotron Laboratory's normal activities is provided from four sources:

(1) the U. S. Atomic Energy Commission, through a Special Research Support Agreement Contract AT(11-1)-1760,

(2) Washington University, through its contribution to contract $\operatorname{AT}(11-1)-1760$,

(3) various research users of the Laboratory's facilities, via purchases of cyclotron time (if the research is 
not supported by the AEC), or of shop time, or by assuming partial responsibility for certaln wages or salaries, and

(4) sale of cyclotron-produced isotopes to hospitals. That part of the Laboratory's support whtch is provided by Washington University and the Atomic Energy Commission jolntly via contract $A T(11-1)-1760$ (items 1 and 2 above) is only sufficient to underwrite what we call a "basic minimal level of operation." By this is meant daytime (only) operation for a flve-day week (1.e., 35 hours per week, excluding start-up time each morning), plus maintenance and repairs, plus minimal attention to development of improvements. It covers staff salaries, minimal expenses, minimum electrical power, and indirect costs (based on salaries) sufficient for that basic level of operation. It does not cover additional costs which are incurred when operat1ons are expanded beyond the "bagic" level.

Since November, 1967, when contract AT(11-1)-1760 first went into effect, the Cyclotron Laboratory's level of operat1ons has always proceeded at a much higher rate than the "bas1c minimal level." Extensive use has been made of both evening and weekend operation, on a regularly-scheduled format; partt1me operators have been hired and trained to handle the extended operations; the second machinist has been employed both to help with the additional ma1ntenance burden and to increase the shop's capability to serve the users through construction of research apparatus; and additional power and other expenses have been provided. The extra funding needed for expanded opera- 
tions has been obtained as listed under item (3) above, supplied by users through purchases of cyclotron time and shop time, etc. Whenever the extra income has been insufficient, we have had to limit the amount of part-time operator employment and have encouraged more use of researchers as their own operators during night and weekend rung. Th1s is not wholly desirable, because inexpert operation unfortunately of ten leads to excessive maintenance and other difficulties later. By and large, however, the amount of "outside" income has roughly approximated the need, and, in particular, has been sufficient to employ a second machinist full time for the last several years. During this period, we have consistently been able to schedule up to 105 hours of machine time per week for our users and for routine maintenance, compared w1th the 35 -hour "basic" capability. Fortunately, the cost for expanding weekly service is considerably smaller per hour than is required to provide the "bas1c" level, which 1ncludes large 1tems for salaries and indirect costs.

This Technical Progress Report contains a summary of operations and accomplishments for the cyclotron Laboratory covering the 12 months ending May 31, 1973, at which time preparation of the Report was begur, Reference may be made to similar earlier reports (co0-1760-1, -2, $-3,-4,-5)$, covering operations in the preceding years since November 1, 1967, when contract AT(111)-1760 f1rst started. The remainder of the Report has three sections: 
(a) Summary of Cyclotron Use During the Year

(b) Improvements

(c) Other Expenses, Other Income.

For reference, several figures have been included. Fig. I shows

a plan view of the cyclotron vault and the adjacent research apparatus area, separated by a concrete shielding wall, while Fig. 2 showg the positions of several important modules in the beam extraction system. FIg. 3 pictures the principal dataacquisition station, also in the control room. The remaining figures relate to the section on Improvements. 


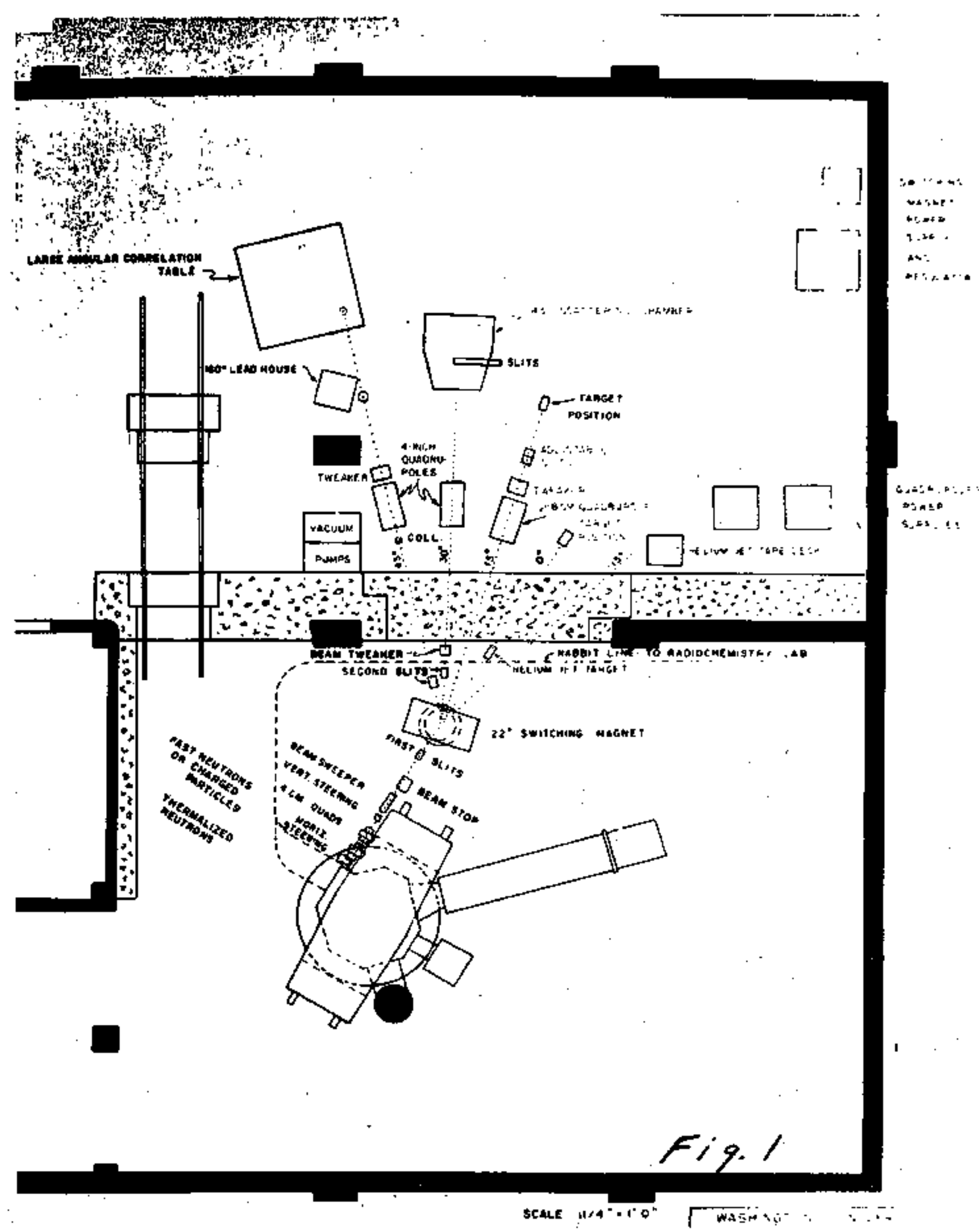




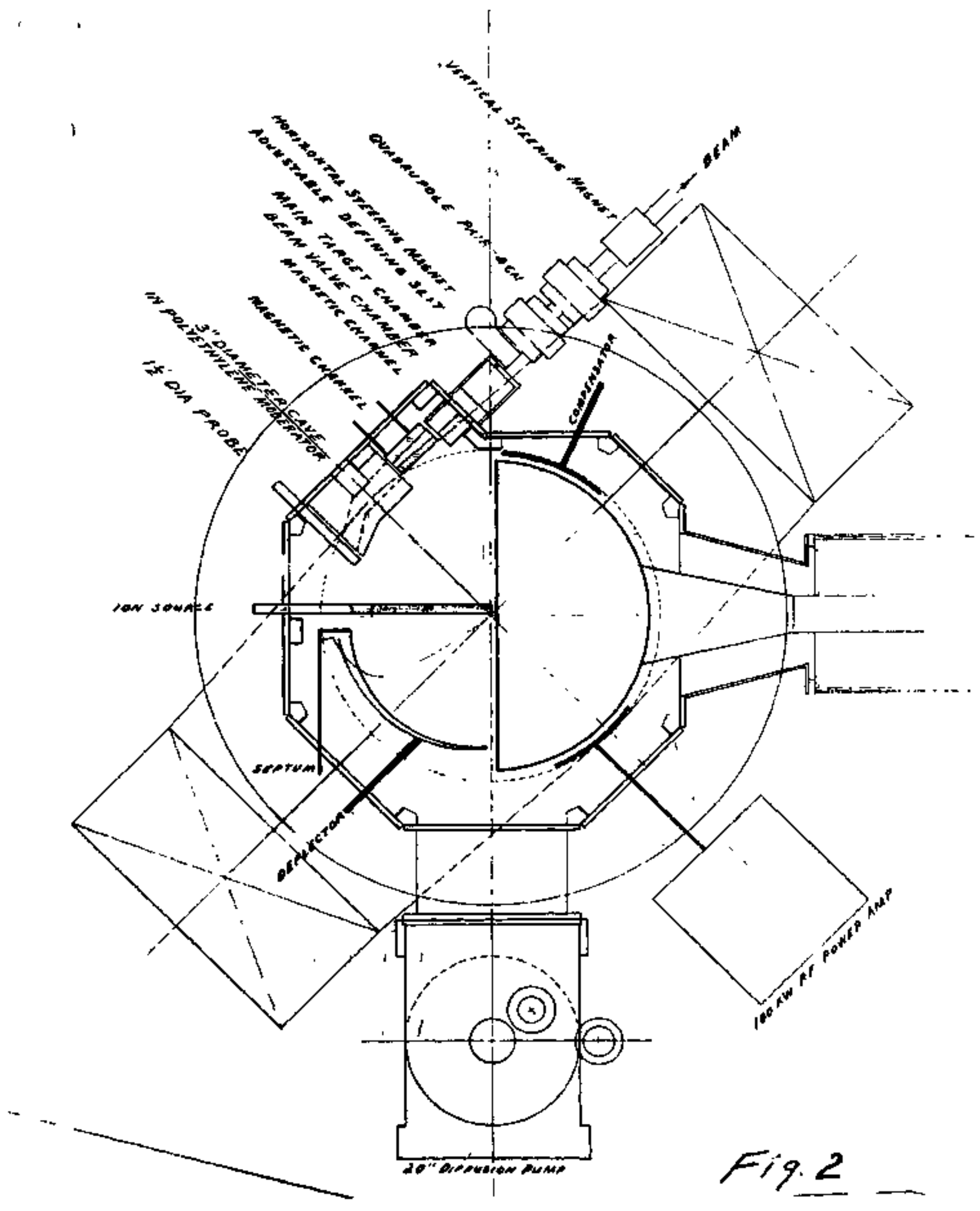


(Hours)

Monday

Tuesday

Weanesday

Thursday

Friday

Saturday

Sunday

$\left\{\begin{array}{l}C \\ R\end{array}\right)=$ Department of Chemistry

Maintenance \& improvements 4

Sarantites (C)

Nuclear Medicine ( $R$ )

Welch (c)

Wahl (c), Gaspar (c)

deuteron runs to

obtain neutrons

cooling off period

Sarantites (c)

Sarantites (c)

Sarantites (C)

Nuclear Medicine $(R)$

Welch (C)

Wabl (c), Gaspar (c)

deuteron runs to

obtain neutrons

cooling off period

Sarantites (c)

Sarantites (c)

Sarantites (c)

11

Maintenance \& improvements 4

Maclas (c)

11

1 Nuclear Medicine (R) I

2 Welch (c) ?

7 Wahl (c), Gaspar (c) 7

deuteron runs to

obtain neutrons

1 cooling off period

1

4

15 Macias (c) 15

15 Sarant1tes (C) 15

1 Nuclear Medicine (R) 1

2 Welch (C) 2

7 Wahl (c), Gaspar (C) 7

deuteron runs to

obtain neutrons

1 cooling off period 1

5 o'falion, Foster (UMSL) 5

15 O'Fallon, Foster (UMSL) 15

15 Macias (c) 15 
SUMMARY OF CYCLOTRON USE DURING THE YEAR

Variable Nature of Research Uses of Cyclotron Time

Unl1ke the normal procedure at many accelerator installations, we provide each of our frequent users of the cyclotron with one or more regularly-scheduled time periods each week (bi-weekly for some). Use of the machine is rotated among the several faculty members involved, each of whom (usually) has several research students working under him. This necess1tates frequent changes in the nature of eyclotron operation, accompanied by changes of particle-type, particle energy, beam Intens1ty, beam direction, etc. This procedure might seem highly Inefficlent, but it proves to be quite workable, on the whole, for the kinds of research we do. Over several years, the laboratory staff has developed deft capabilities as "quick-change" artists.

The basis for this division of time among users is our Normal Bi-Weekly Schedule (preceding page). Th1s schedule, which undergoes revision by negotiation among intereated parties at irregular intervals, assigns fixed hours for each researcher during two weeks of 15-hour days, beginning at 8:30 AM each day. The eight hours from 8:30 AM to 4:30 PM are designated as "prime time," which is especially desirable because this is when the full-time operating staff is on duty. During non-prime time (the other seven hours per day), the cyclotron is run by parttime operators. The schedule has been designed to divide prime 
time as equitably as possible among (1) Chem1stry Department users, (2) regular weekly majntenance and improvement work by the staff, and (3) brief periods twlce weekly for routine production of $\mathrm{F}^{18}$, a medically-useful radioisotope, for the University's School of Medicine, Department of Nuclear Medicine, and several local hospitals. Non-prime time is principally divided up among Chemistry Department users, but some of it, notably Friday evening and Saturday every other week on the current schedule, has been assigned to non-AEC supported users. $A s$ an interesting side-light, the use of cyclotron time by Dr. Charles Foster of the University of Missourl at St. Louis is the result of an interesting and mutually-profitable arrangement between sister institutions in the St. Louls area. Lacking funds to buy cyclotron time outright, Dr. Foster arranged an exchange agreement, whereby his use of our cyclotron Laboratory is repaid by reactor time made avallable to varlous Washington University researchers at the Research Reactor Fac1lity of the University of Missouri at Columbia, Missouri. This barter arrangement has been in effect since November, 1971. During the past year, eight Washingtion University scientiste made use of the Reactor Facility without charge under th1s plan. This is an encouraging instance of cooperation among neighboring universities for mutual benefit in these times of tight funding for research.

Variations from the Normal Bi-Weekly Schedule are always possible by mutual arrangement. Some researchers are not always 
able. to use $100 \%$ of their assigned time. If agreeable to them, others sometimes move in. Also, there is occaslonal long-run use of the machine during the normally unscheduled middle-orthe-night hours. Table I on the next page summarizes actual use as contrasted with scheduled use. The time unit called "machine hours" represents time when the use of the machine 1s precluded for anyone elge because of occupancy by the current user, whether he is actually running beam onto his target, suffering from temporary breakdowns, or waiting between runs for chemical processing to take place.

Note In Table I that machine hours actualiy used totalled 2135.0 for the twelve-month period, to be compared with 5460 machine hours scheduled on the Normal Bi-Weekly Schedule (52 weeks $\times 7$ days $x 15$ hours), of which 2080 hours are scheduled prime time. Note also that only about $60 \%$ of "mach1ne hours" involve actual beam on target. In other words, a typical researcher is not actually using the beam about $40 \%$ of his time, but is performing other operations or suffering the frustrations of temporary breakdown.

Table II (on the same page as Table I) divides up the actual beam hours for one year according to type of particle being accelerated. Compared to the simflar entry in our report of a year ago, the re have been no big changes, except that the use of protons by Prof. Sarantites and his students for studying proton-induced gamma-transitions, as a highly-profitable technique for elucldating nuclear energy level schemes, has 
diminished. This decrease of proton use is somewhat misleading. A large part of the proton work in preceding years was developmental in nature, where nowadays the procedures and techniques are well-established and experiments are done more efriclently. In addition, the preparation of several research papers reportIng data acquired earlier has slowed down the rate of undertaking new experiments, but only temporarily.

Table III (covering four pages) goes even further than Table I in breaking down the utilization of the cyclotron by various users. The rirst two pages of Table III show the machine hours actually used during prime time according to uger and month, while the last two pages do the same for non-prime time. The analysis of prime time usage makes clear how much more valued prime time appears to be: total actual use for the year was 1780 machine hours out of 2080 hours of scheduled prime time (85x used). By contrast, only 547 hours of non-prime time was actually used, out of 3380 hours of non-prime time on the Normal Bi-Weekly Schedule ( $16 \%$ used). Again, the principal cause for less use of non-prime time has been a temporary slowdown by Dr. Sarantites on undertaking new experiments, in order to catch up on the preparations of research papers. His situation was further complicated in that he had fewer graduate students than usual. He has recently taken on several new students, and expects his use of machine time to go up appreciably next year.

- Another datum derivable from Table III is the fraction of total hours which were used by Chemistry Department researchers 
Table I. Monthly Actual Use

$$
6-1-72 \text { to } 5-31-73
$$

$\begin{array}{lccc}\text { Month } & \text { Nachine Hours } & \text { Bean Hours } & \begin{array}{r}\text { Maintenance and } \\ \text { Improvenent Hours }\end{array} \\ \text { June } 1972 & 203.5 & 137.6 & 16.0 \\ \text { July } & 121.5 & 74.9 & 16.0 \\ \text { August } & 113.5 & 56.9 & 16.0 \\ \text { September } & 151.0 & 98.0 & 16.0 \\ \text { October } & 186.5 & 100.3 & 16.0 \\ \text { November } & 122.0 & 49.8 & 16.0 \\ \text { December } & 239.5 & 135.5 & 16.0 \\ \text { January } 1973 & 149.5 & 69.0 & 16.0 \\ \text { February } & 145.0 & 64.1 & 16.0 \\ \text { March } & 279.5 & 183.8 & 16.0 \\ \text { April } & 238.0 & 134.6 & 16.0 \\ \text { May } & 185.5 & 96.0 & 16.0 \\ & 2135.0 & -1200.5 & 192.0\end{array}$

Table II. Breakdown of Beam Hours by Ion Type
Hellum 3
355.3
Alphas
631.2
Deuterons
157.2
Protons
45.2
Carbon 12
4.7
Cyclotron Tune
6.9
1200.5 
(Drs. Wahl, Sarantites, Macias, Gaspar, Welch and their students or associates), most of them on projects recelving AEC support via research contracts. Of prime time, these users consumed 1404 machine hours out of the 1780 that were used $(79 \%)$, while they consumed 397 of 547 non-prime time machine hours (73\%). The other princlpal expenditure of prime time was for regular cyclotron tuning and matntenance (11\%).

As in prior years, Table IV has been included to 1llustrate the extreme divers1ty of the demands made by our users. It 11sts each of the (approximate) energy values required at one time or another during the year for each of flve alf ferent accelerated particles. Parenthetical data give typical largest currents in the Main Target Chamber (see F1g. 2 for location) for a few of the entries. 
Table III - Part I

6-1-72 to 5-31-73 Machine Hours. Prime Time (8:30 AM - 4:30 PM Monday - Friday)

1972 June July Aug. Sept. Oct. Nov. N_ Dec.

P. Gaspar (C)

D. Holten

$19.5 \quad 8.0 \quad 21.0$

R. Hwang

G. Stewart

E. Macias (C)

M. Phelps (R)

H. Potratz (C)

D. Barantites (c)

$\mathrm{J}$. Barker

J. Urbon

M. Fowler

N. H. Lu

A. Wanl (C)

G. Goth

G. Erhardt

R. Strickert

E. Vine

F. Walker (P)

M. Welch (C) \& (R)

K. Krohn

M. Loberg

W. U. Eng'r. Dept .

Un1v of Missouri

20.

$8.0 \quad 10$

34.0

17.0

16.0

28.5

40.0

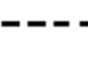

2.0

61.0

19.0

24.5

21.0

22.5

59.0

Nuclear Medic1ne (R)

8.

17.0

23.0

4.0

$-\cdots$

1.5

13.0

14.0

$7 \cdot 5$

Cyc. Maintenance \& Tuning

Total

$\frac{16.0}{164.0} \quad \frac{16.0}{122.5} \quad \frac{24.0}{122.5} \quad \frac{16.0}{132.0} \quad \frac{16.0}{156.5} \quad \frac{16.5}{122.0} \quad \frac{16.0}{181.5}$


Table III - Part II

6-1-72 to 5-31-73 Machine Hours, Prime T1me (8:30 AM - 4:30 PM Honday - Friday)

\begin{tabular}{|c|c|c|c|c|c|c|}
\hline 1973 & Jan. & Feb. & March & April & May & Totals \\
\hline & 12.5 & 12.0 & 16.0 & 15.0 & 23.0 & 184.5 \\
\hline
\end{tabular}
E. Macias (C)
M. Phelps (R)
H. Potratz $(c)$
D. Sarantites (C)
J. Barker
J. Urbon
M. Fowler
N. H. Lu

$\begin{array}{rrrrrr}63.5 & 40.0 & 24.0 & 17.5 & 25.5 & 324.0 \\ --- & 2.0 & --- & --- & 1.5 & 3.5 \\ --- & --- & --- & --- & --- & 2.0 \\ & 16.0 & 76.0 & 67.0 & 42.0 & 408.0\end{array}$
A. Wahl (C)
G. Goth
$G$. Erhard $t$
R. Strickert
E. Vine

R. Walker (P)

H. Welch (C) \& (R)

K. Krohn

A. Lobers

$\begin{array}{llllll}30.0 & 30.0 & 21.5 & 33.0 & 27.5 & 341.0\end{array}$

W. U. Eng'r. Dept.

2.0

$4.5 \gamma$ simultaneous

$---$

$--133.0$

$\begin{array}{lll}10.5 & 13.5 & 14.5\end{array}$

4.5

$7.0 \quad 247.0$

Univergity of Missouri

Nuclear Medicine (R)

9.0

$--$

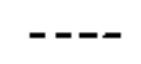

$---$

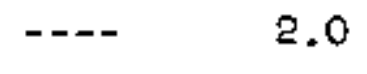

cyc. Maintenance \& Tuning

Total

$\frac{16.0}{148.0} \frac{16.0}{137.5} \frac{16.0}{177.0} \frac{16.0}{161.0} \frac{17.0}{155.5} \frac{201.5}{1780.0}$


Table III - Part III

Machine Hours, Non-Prime Time (Evenings, Nights, Weekends)

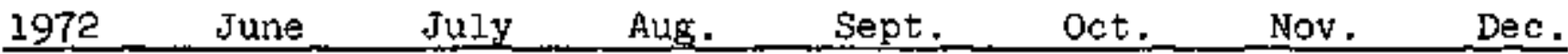

P. Gaspar (C)

D. Holten

R. Hwang

G. Stewart

E. Macias (c)

D. Sarantites (c)

$\mathrm{J}$. Barker

J. Urbon

M. Fowler

N. H. Lu

R. Walker (P)

M. Welch (C) \& (R)

K. Krohn

$M$. Loberg

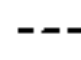

45.5

$---\quad 1.5$

45.5

$\cdots-$

6.0

$\cdots$

---

$-\cdot$

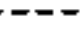

25.0

34.0

8.0

61.0

Total

Grand Total

(Prime + Non-Prime)

$\begin{array}{rrrrrrr}10.0 & 7.5 & 7.0 & 10.0 & 12.0 & 8.0 & 13.0 \\ 55.5 & 15.0 & 7.0 & 35.0 & 46.0 & 16.0 & 74.0 \\ 219.5 & 137.5 & 129.5 & 167.0 & 202.5 & 138.0 & 255.5\end{array}$


Table III - Part IV

Machine Hours. Non-Prime Time (Evenings, Nights, Weekends)

1973 Jan. Feb. March. April May Totals

P. Gaspar (c)

D. Holten

-

$R$. Hwang

G. Stewart

E. Macias (c)

D. Sarantites (C)

J. Barker

J. Urbon

M. Fowler

N. H. Lu

R. Walker (P)

M. Welch (C) \& (R)

K. Krohn

M. Loberg

$\begin{array}{rrrrrr}2.0 & -1 & & 3.0 & 9.0 & 14.0 \\ --- & -.0 & 105.0 & 78.0 & 21.5 & 378.0\end{array}$

Nuclear Medicine (R)

Total

2.0

10.0

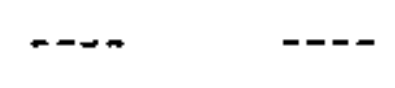

$-18.0$

$\begin{array}{lllll}-2 & 1.5 & \ldots & \ldots & 1.5\end{array}$

Grand Total

(Prime + Non-Prime)

\begin{tabular}{rrrrrr}
13.5 & 12.0 & 13.5 & 12.0 & 13.5 & 132.0 \\
\cline { 5 - 6 } & 23.5 & 118.5 & 93.0 & 46.0 & 547.0 \\
165.5 & 161.0 & 295.5 & 254.0 & 201.5 & 2327.0
\end{tabular}


Table IV. Particle Energies \& Some Maximum Currents in the Main Target Chamber

$$
\text { 6-1-72 to 5-31-73 }
$$

\begin{tabular}{|c|c|c|c|c|c|}
\hline alpha & & $3_{\mathrm{He}}$ & $\underline{p}$ & & $\underline{d}$ \\
\hline 12.25 & $\mathrm{MeV}$ & $19 \mathrm{MeV}(38 \mu \mathrm{a})$ & 4.5 & $\operatorname{MeV}(20 \mu a)$ & $13 \mathrm{MeV}$ \\
\hline 12.3 & $\mathrm{MeV}$ & $21 \mathrm{MeV}(15 \mu \mathrm{a})$ & 10 & $\mathrm{MeV}$ & \\
\hline 13 & $\mathrm{MeV}$ & $25 \mathrm{MeV}$ (15Ha) & & & \\
\hline 14 & $\mathrm{MeV}$ & $29 \mathrm{meV}$ & & $12 c^{4+}$ & \\
\hline 15.7 & $\mathrm{MeV}$ & $30 \mathrm{MeV}$ & & $38 \mathrm{MeV}$ & \\
\hline 16 & $\mathrm{MeV}$ & $34 \mathrm{MeV}$ & & & \\
\hline 18 & $\operatorname{MeV}(24 \mu a)$ & $35 \mathrm{MeV}$ & & & \\
\hline 19 & $\mathrm{MeV}$ & . & & & \\
\hline 20 & $\mathrm{MeV}$ & & & & \\
\hline 21 & $\mathrm{MeV}$ & & & & \\
\hline 22 & $\mathrm{MeV}$ & & & & \\
\hline 24 & MeV & & & & \\
\hline 26 & $\mathrm{MeV}$ & $\cdot$ & & & \\
\hline 29 & $\mathrm{MeV}$ & & & & \\
\hline 30 & $\mathrm{MeV}$ & & & & \\
\hline
\end{tabular}




\section{IMPROVEMENTS}

As in previous Reports, discussion of improvement projects undertaken during the year has been broken down into three categorles:

(a) Projects intended to improve either the reliability or the convenience of operation of the cyclotron itself.

(b) Projects aimed at general improvement in the utility of the" laboratory or the accelerator for research users, but having no specifle user in mind.

(c) Projects directly gasociated with the research of some particular user, orten shop work which might otherwise have been performed in some departmental shop.

To Improve Reliability and Convenience of Operation

1. Fallure of the cyclotron roughing vacuum pump, which was orlginally Installed in 1950, necessitated the purchase and installation of a new Kinney Model KDH130 pump to replace it, having a pumping capacity of 131 cuble reet per minute.

2. The radiofrequency system of the cyclotron 18 driven by an $r . f$. power supply embodying a single main power tube. When the cyclotron was converted to sector-focusing operation in 1964, two 4CW50,000 Elmac power tetrodeg were purchased for this supply, one as a spare. These tubes have been alternated In service during the past elght years, and flnally both 
falled In March, 1973. Since B1mac no longer manufactures th1s tube type, they were replaced with 4Cw100,000 tetrodes, which required some modifications of water and electrical connections because of the somewhat different physical dimensions of the new tubes.

Both of the above items are good examples of why we do not attempt to plan our equipment purchases in advance. Many of our equipment items are bought to replace ones that have falled in service, and we cannot predict very accurately what will need replacement next.

3. The motor-driven tuning choke for the control grid of the 4CW100,000 tube in the r.f. power supply has given trouble for a couple of years tue to arcing across insulators and occasional motor failure. Accordingly a new system was built and installed, which 1ncorporates better insulation and placement of components.

4. A small vacuum pump and associated plumbing were installed for the purpose of Improved helium cooling of some kinds of targets which are exposed in the Main Target Chamber. This is connected with an insert for the chamber which places a vacuum isolating foll between the target region and the main cyclotron acceleration chamber, which is at good vacuum.

To Improve General Research Utility

1. A high-voltage pulse amplifier (Fig. 4) was designed and constructed to drive the beam-sweeping electrodes of an auxillary beam-control system we have been developing for 
Dr. Sarantites and Dr. Maclas the past year or so. It ampl1fled the output of a commercially-obtalned pulser purohased earlier. Short pulses of electrostatic deflection periodically allow the beam to pass through an aperture downstream and reach a target in the research room. These on periods are followed by OFF periods of adjustable length, during which a counter detects radiations from any short-lived isotopes formed in the target during the preceding on period. The system was tested on beam, and functioned satisfactorily for ON periods ranging from 10 to $1000 \mathrm{r}, \mathrm{f}$. beam bursts in duration. Subsequent improvements in c1rouitry, pirinc1pally through use of a higher-power triode, led to improved rise and fail times, and we were able to reduce the minimum length of an oN period to $5 \mathrm{r}$. f , beam bursts. Further work is underway aimed at reducing the mintmum length to 2,3 , or 4 bursts.

2. Power supplies. (Fig. 5) wh1ch had been purchased for the High Voltage Ion Source (3000 volt, 2 ampere) and the Beam Sweeping System (5000 volt, I ampere) were installed in the alcove adjacent to the control room of the cyclotron. Earlier tests of both systems on beam were conducted using a lowervoltage supply borrowed from the evaporation chamber apparatus and temporarily modifted for the purpose. A current regulator for the High Voltage Ion Source power supply. was constructed, incorporating a saturable reactor pirated from the power supply for a magnet which at one time was used for model 
tests in redesigning the cyclotron magnetic field. The regulator was also installed in the alcove.

3. An adjustable overvoltage-undervoltage a.c. power line safety system was designed, and two un1ts were constructed and installed. One $1 \mathrm{~s}$ in the cyclotron Laboratory, the other in the Radiochemistry Laboratory, on circusts which feed the pulse-height analyzers and other equipment at datataking stations (F1g, 6).

4. Cold trap sections (Figs. 7,8 ) were built for two of the beam tubes leading 1nto the research room. They are intended to condense 011 and other vapors which might otherwise deposit on taroet surfaces as a contaminant. Each consists of two concentric tubes about three feet long, which are thermally-insulated from one another. The outer tube is at room temperature, while the inner one connects to a "cold finger" which is kept immersed in liquid nitrogen.

5. A convenient atlas has been assembled of excitation functions of nuclear reactions induced by particles with energies appropriate for our cyclotron. Data have been copied from varlous Journals and indexes, and arranged for quick, easy reference.

6. Two minor projects were associated with neutron work. A water-cooled beryllium target was constructed for neutron production in the research room. A 15 microampere beam of $13 \mathrm{MeV}$ deuterons onto this target has been achieved. A paraffin-cadrium transportation contalner was construeted 
for the Pu-Be neutron sources which are used as calibration standards and in laboratory courses.

In Ald of Specific Research Experiments

A lot of shop time and engineering effort by the cyclotron Laboratory staff goes into projects falling into this category, and it seems appropriate here to dwell upon the changing character of the demands for shop time and engineering services during the past three years. The primary function of our shop machinists and cyclotron engineers is to run an accelerator, which entails numerous maintenance chores, repair of equipment, design and manufacture of new equipment to improve the accelerator and the usefulness of the Laboratory, etc. There is always a backlog of work of this kind, having to do with the cyclotron 1 tself and the laboratory. But more and more 1t has become common for researchers using the Laboratory to ask the staff to work on the research projects themselves. The princlpal motivations have been (1) time, (2) design expertise, and (3) high quality or workmanship. The chemistry department shop is perfectly capable of dolng excellent work, but is required to serve such a large constituency that it often is forced to proceed very slowly with relatively big jobs of the kinds put in by Drs. Wahl, Sarant1tes, Macias, et. al. Time delays of many months are not uncommon because of the pressures to work on many small jobs from other chemistry faculty members. Nor does the chemistry department have any kind of professional design personnel for apparatus, and faculty members and graduate students have to be their own 
engineers. By contrast, the Cyclotron Laboratory ataff lncludes several persong who have worked with cyclotrons and nuclear apparatus for many years, who understand the kinds of problems that are likely to come up and are experienced with techniques and designs to meet them. They have the additional advantages of being thoroughly famillar with the cyclotron shop and machinists. And, finally, our machinists thenselves have become skilled. and knowledgeable in the fabrication of cyclotron-related equ1pment, and are guite familiar with the unusual conditions under which 1t has to operate.

Several of these projects which we worked on thts year are l1sted below, one of them in sufflolent detall to give some notion as to the high degree of ingenuity and sophistication which are often required. Estimates are given of the amount of shop time (man-hours) expended on each by our two machinists. We could make a strong case for expanding our shop staff to three machinigts, and the shop is big enough to allow this, if our income were sufficient to pay another machinist. Similarly, we feel that more electronics help would be most worthwhile, if we could afford it.

1. The eka-radon search apparatus (ERSA) was completed, requiring 416 hours of shop time. This project for Dr. Wahl and

- Dr. Goth was reported in considerable detall in last year's Report, and the time expenditure is in addition to 520 hours reported then. various preliminary tests on it were run using our own alpha-particle beam, concerning foll heating, view1ng of the focus screen, outgassing of the stearate layer, 
etc. Padded cases were constructed for transporting the assembly to the Super Hilac Laboratory. At the Hilac Iab, ERSA was tested briefly with "Iight" ions (argon) in the absence (as yet) of the kind of very heavy ion beams for which the experiment calls (e.g., mercury).

2. A light ion search apparatus (IISA) has been designed and constructed (Figs. 9,10), and is now undercoing various preliminary tests here. It is 1ntended to supplement ERSA, by searching for eka-radon using the lighter-1on beans already avallable at the Hilac laboratory. Instead of having a bigmuth foll target and stearate emanation layer which are separated from one another, as in ERSA, the target is urantum, 1ncorporated directly into the emanation layer (uranyl stearate). Direct 1rradiation of the gtearate layer $1 \mathrm{~s}$ poss1ble in LISA but not in ERSA, because the energy carried by (e.g.) krypton lons from the H1lac 1s much gmaller than by mercury lons, and consequently melting of the stearate can be avoided, at least in sufficiently brief exposures. The krypton beam enters from the right (FIg. 9) and hits the stearate, which is packed behind beryllium protecting foils into four recesses in a rotating nolder (Fig, 10, also slightIy visible through an open port in Fig. 9). The holder rotates at 20 seconds per revolution, and no part of the stearate is exposed to the beam for more than $1 / 3$ of a second. As In ERSA, detection is to be by observation of fission tracks In a mica or plastic film in an evacuated space behind the stearate in the rotating holder. So far the IISA project has 
required 223 hours of shop time.

3. Modifications were made in the rotating beta recoil assembly for Prof. Wahl, which was discussed in some detail in this section of last year's Report, at which time it had already required 380 hours of shop time. An additional 139 hours have gone into the modifications, which lnclude the addition of a thin rubber gasket under the Teflon "squirrel cage" to obtain better vacuum sealing, and a redesign of the rlattened hollow cone which separates the $\mathrm{U}^{235}$ source from the rotor on which fission-product atoms deposit. The new cone is built in four Insulated metal sections which contact electrical feed-throughs in the chamber wall. The purpose 1s to obtaln a voltage gradient over the entire 3-centimeter space separating the $\mathrm{U}^{235}$ from the rotating collector roils (to get more effective deposition), rather than over only a few militimeters as formerly.

4. A large angular correlation table ( 6 feet by 6 feet) was constructed for Prof. Sarantites (F1gs, 11,12) and was installed on the $45^{\circ}$ beam tube somewhat downstream from the rotatable lead-house which they have been (and still are) using for the study of angular dependence of gamma rays. The new table accommodates a rather cumbersome counter arrangement, in which the detector is mounted at the far end or a long cold finger extending about 30 inches from the Dewar containing the coolant (not shown in the figures). The small scattering chamber is equipped with a flxed counter also, so that correlations between gamma rays and particles 
can be studled. The heavy lead shlelded detector shown in the figures is one intended to emphasize very energetic gamma rays by suppressing less energetic ones. The table, scattering chamber, and movable lead shield required about 223 hours of shop time.

5. Some 570 hours of shop time so far and a very large (but unrecorded) amount of engineering time have gone into the development and construction of what we have been calling a helium jet transfer system (HJTS) for Prof. Maclas (FIgs. 13-20). Basically the idea 18 to study short-lived radioisotopes produced in cyclotron bombardments, but to do the necessary counting at a location which is some distance - away from the bombarded target. Moreover, the measurement of decay times is accomplished by depositing the radioactive atoms on an intermittently moving tape at one place and detecting their decay products with a counter situated about 8 inches downstream from the deposition site.

Figs. 13-16 show three successive versions of the target assembly, illustrating the evolutionary character of the development of this apparatus. The target material is a foil or 1a deposited on the backside of a foil, and the radioactive atoms recoll out of the target more or less In the same direction as the incident beam from the cyclotron. The space behind the target is continuously flushed with helium which has been saturated with vapor (several different kinds of vapor are used alternatively); the recolls 
tend to "cluster" with vapor particles, and are thus entrained by the helium gas, which moves them along toward the counting apparatus (tape deck). The transfer time is speeded up by passing the hellum out of the "clustering" region In the target assembly through very fine capillary tubing (some seven or eight feet long) to the tape deck. The target assembly is positioned in the cyclotron room (Fig. 16) jugt in front of the concrete shielding wall. The capillary tubing is led through the concrete wall to the tape deck in the research room on the other side. Fig. 17 shows a bubbler apparatus for saturating the helium with any of three different vapors.

Flgs, 18-20 show varlous views of the tape deck and detector assembly. The tape is seen entering at the nearer end, and the capillary tube (Teflon) is seen entering a deposition assembly nearby. Fig. 20 shows a counter window about eight inches from the deposition site, while the other pictures show a detector and shield positioned in front of the window. The tape 18 moved eight inches at a time, moving the most recent deposit in front of the counter. The ent1re housing through which the tape passes is pumped continuously, which requires that the tape enter and leave through crude vacuum seals. 
OTHER EXPENSES, OTHER INCOME

It was pointed out in the Introduction that the funding of Cyclotron Laboratory operations by the AEC and Washington University via contract AT(11-1)-1760 is sufficient only to provide the "basic minimum level" of operations. This section summarizes information about the additional expenditures (and additional income to cover them) which were made to extend operations to include evenings and weekends, and, most particularly, to increase our machine shop staff. The first chart below tabulates the extra expenses, and compares them to anounts available from AT(11-1)-1760 for comparable items under the "basic minimum level." Note that the contract year does not end until october 31,1973 , so that the numbers given for actual expenses include estimates for the period June through oetober. Numbers have been rounded off, and are given in thousands of dollars $(K \$)$.

Item

Budgeted in Total actually Excess spent AT(11-1)-1760 spent (est.) over budget (est.)

Salaries, wages, and indirect costs based on salaries, plus fringe benefits $111.9 \mathrm{K \$}$ $139.8 \mathrm{~K} \$$ $27.9 \mathrm{~K} \$$

Supplies, materials, services

Equipment

$9.5 \mathrm{~K} \$$

$10.6 \mathrm{~K} \$$

$1.1 \mathrm{~K} \$$

Power

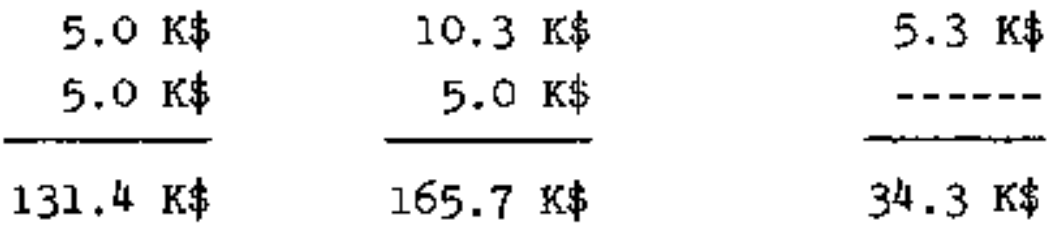


The $27.9 \mathrm{~K} \$$ of extra salary-related costs breaks down approximately as follows: second machinist, including salary, overhead, and fringe benefits $20.3 \mathrm{~K} \$$

extra operators $\quad 5.6 \mathrm{~K} \$$

extra part-time help, draftsmen, general labor, wages $2.0 \mathrm{~K}$

$27.9 \mathrm{~K} \$$

The outside income by which the extra costs of $34.3 \mathrm{~K} \$$ are supposed to be covered include the following:

From Dr. Wahl, $10 \%$ for four months of the second machinist, salary, overhead, fringe, from research grants

$0.8 \mathrm{~K} \$$

From Dr. Ter-Pogossian, Department of Radiology, $75 \%$ for four months, $100 \%$ for eight months, of second machinist, from a research grant $18.6 \mathrm{~K} \$$ Sale of $\mathrm{F}^{18}$ for medtcal purposes $10.8 \mathrm{~K} \$$

Sale of irradiation time to non-AEC users, including Drs. Wahl, Welch, walker $4.1 \mathrm{~K} \$$

Sale of hourly shop time $0.0 \mathrm{~K} \phi$ $34.3 \mathrm{K \$}$

The last three entries above are estimated, since they are projected ahead to the end of the contract period on october 31 , 1973. Failure to achieve the estimated incomes from Irradiation and hourly shop work would require us to cut back in some way near the end of the contract year. 


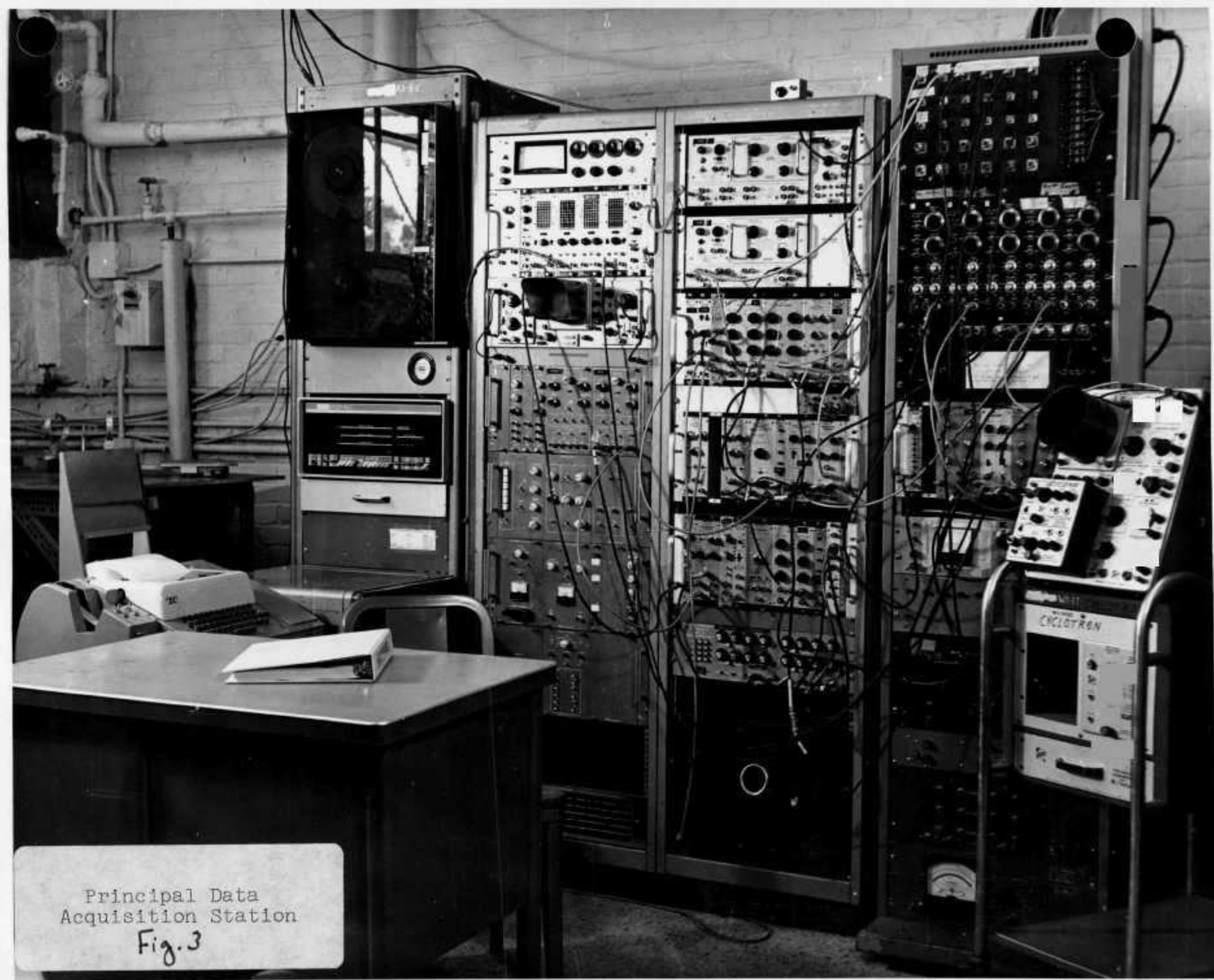




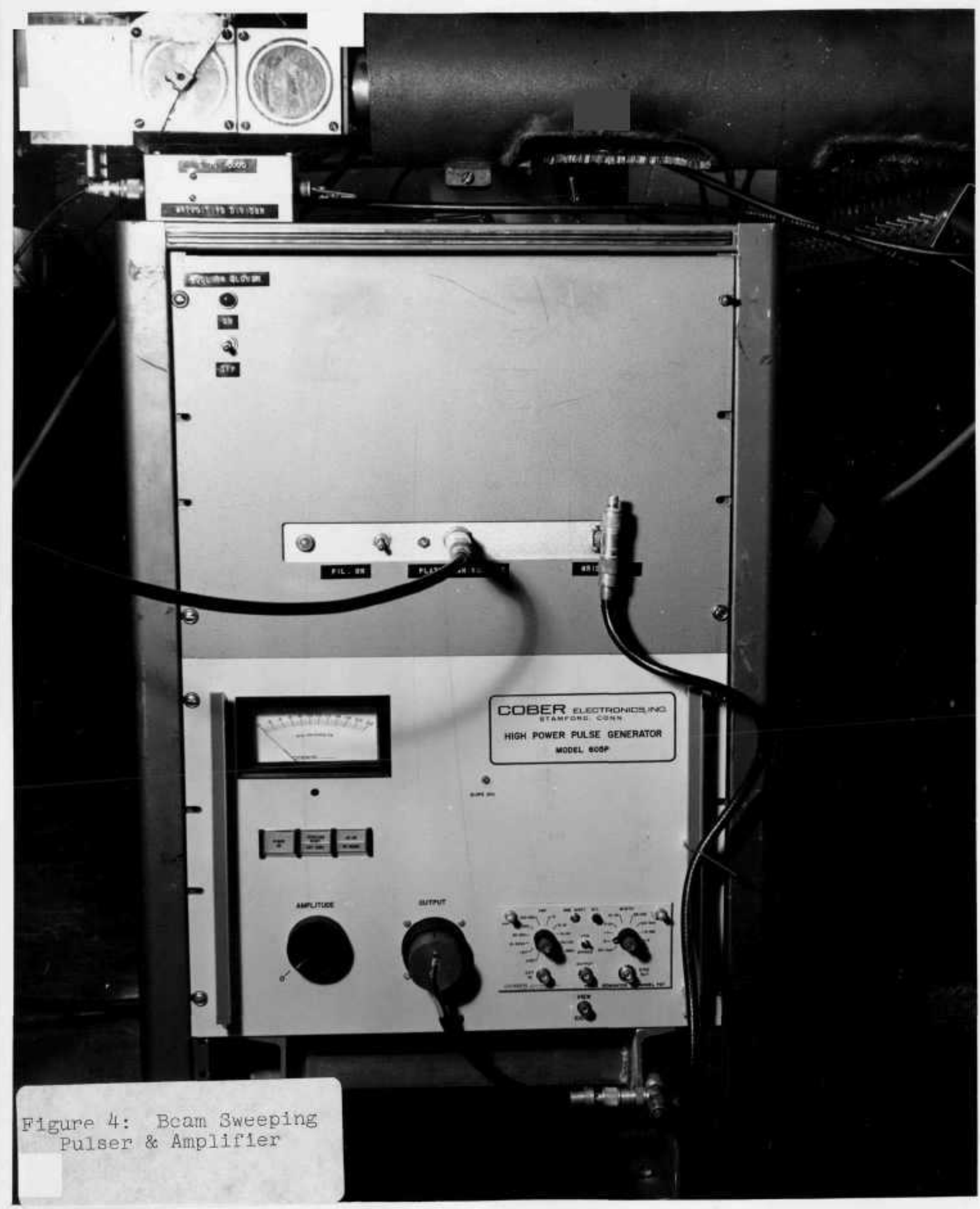




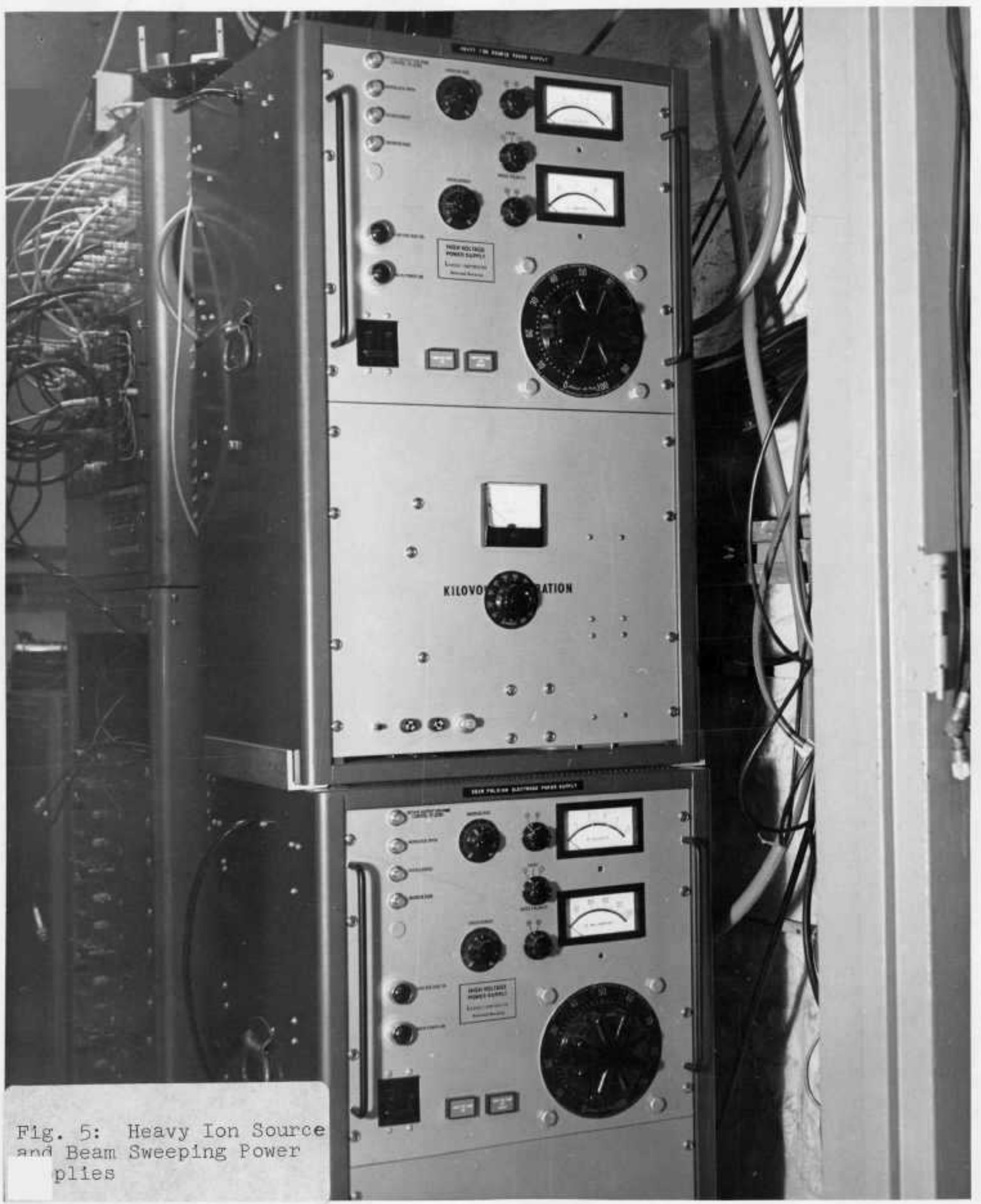




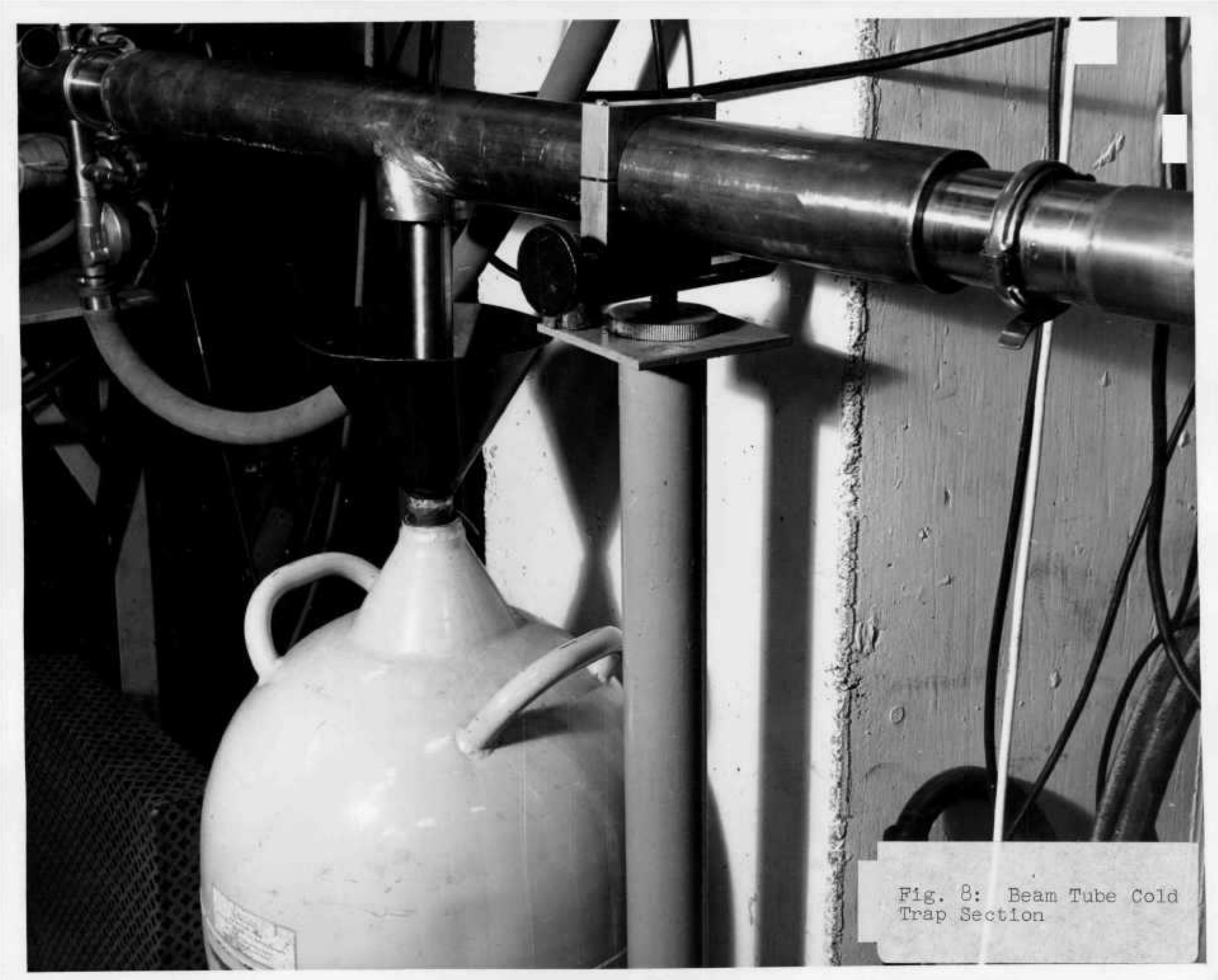




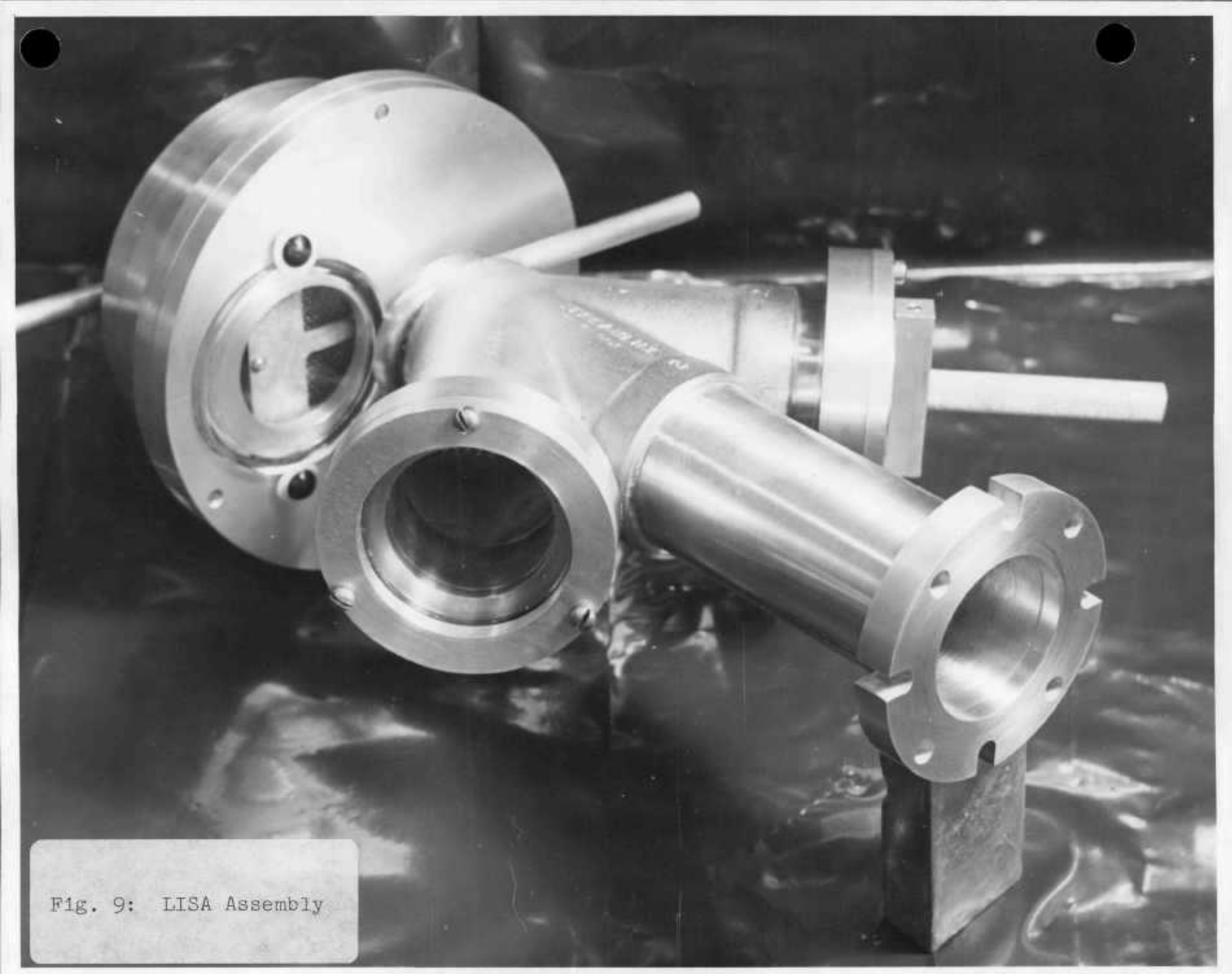




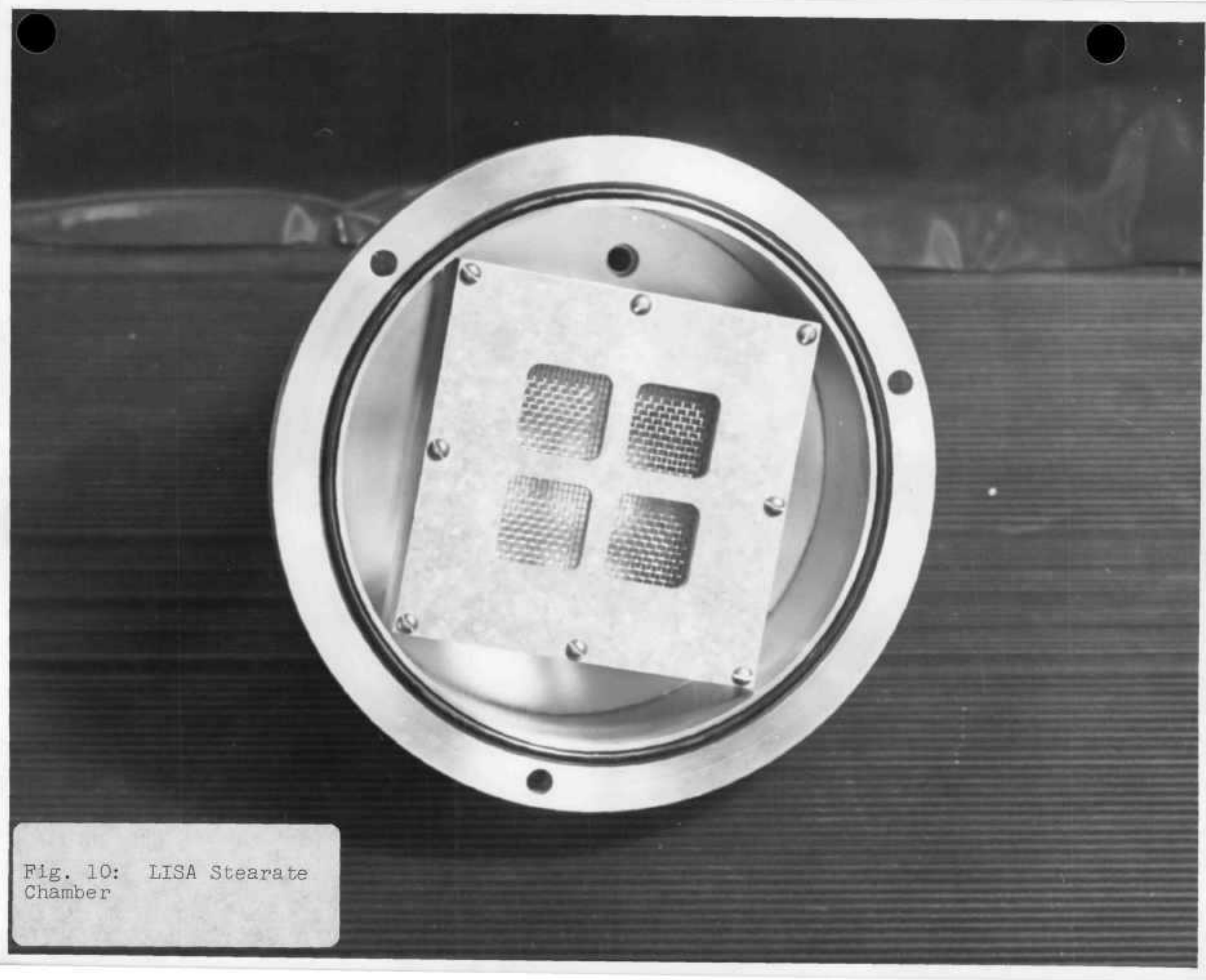




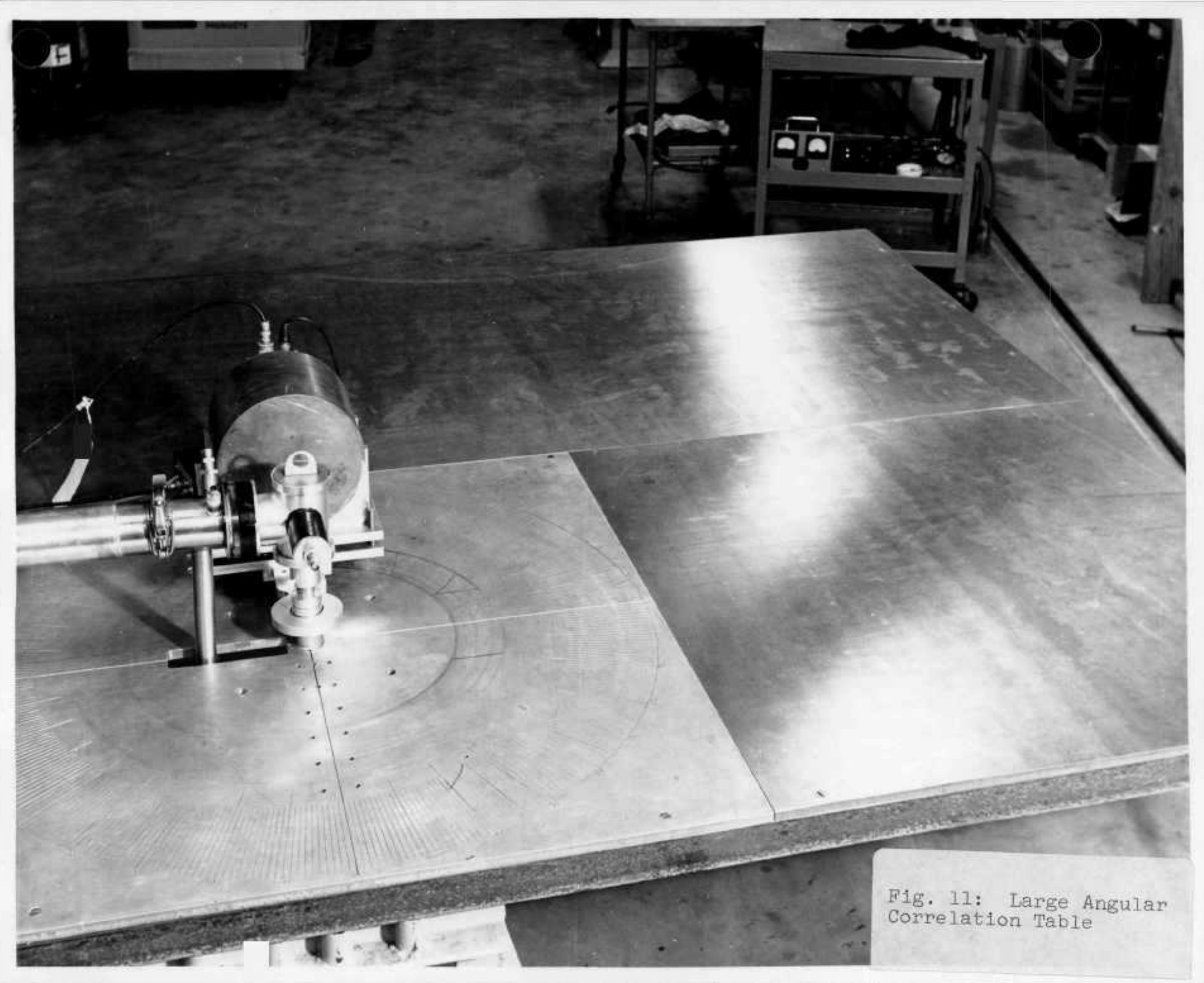




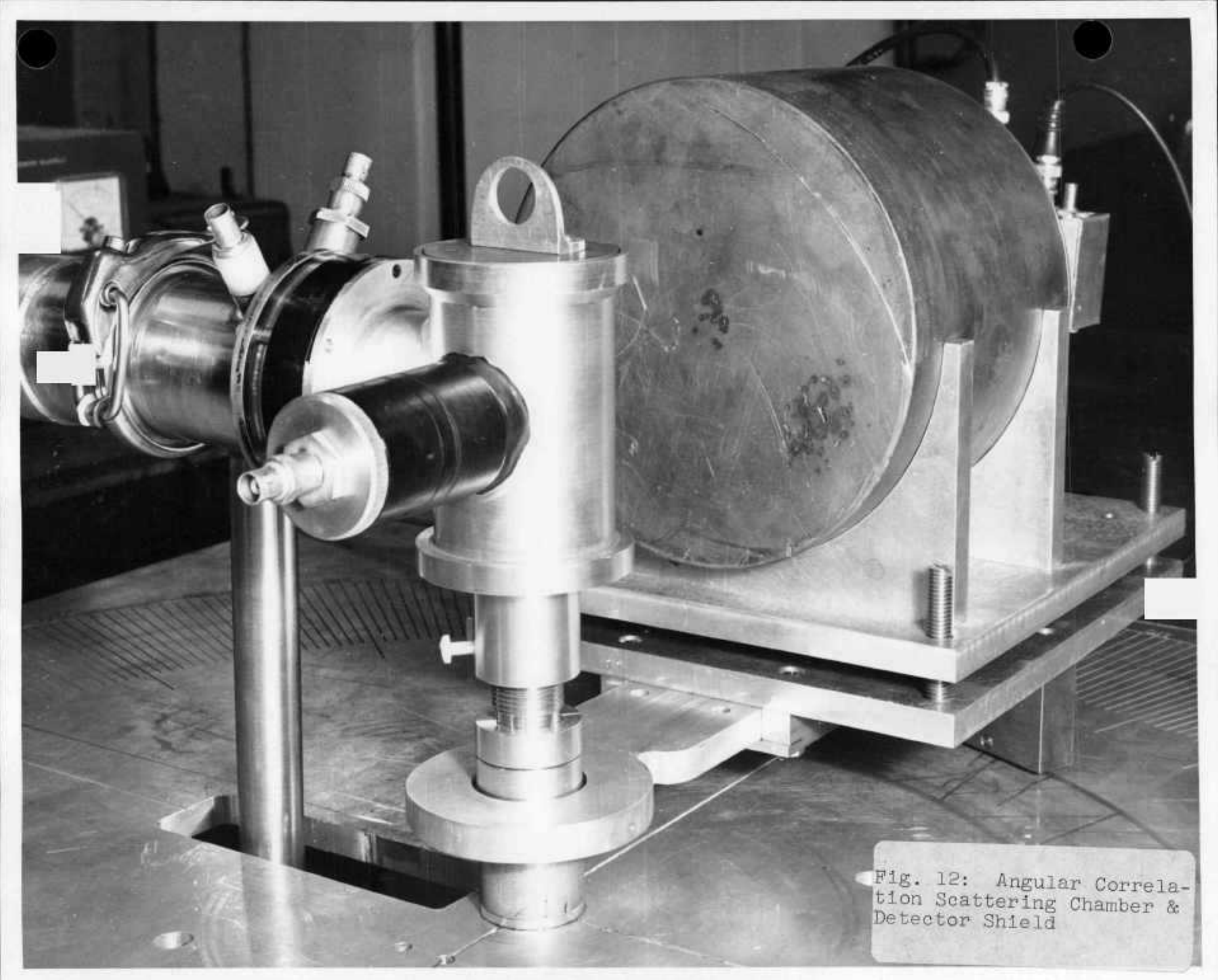





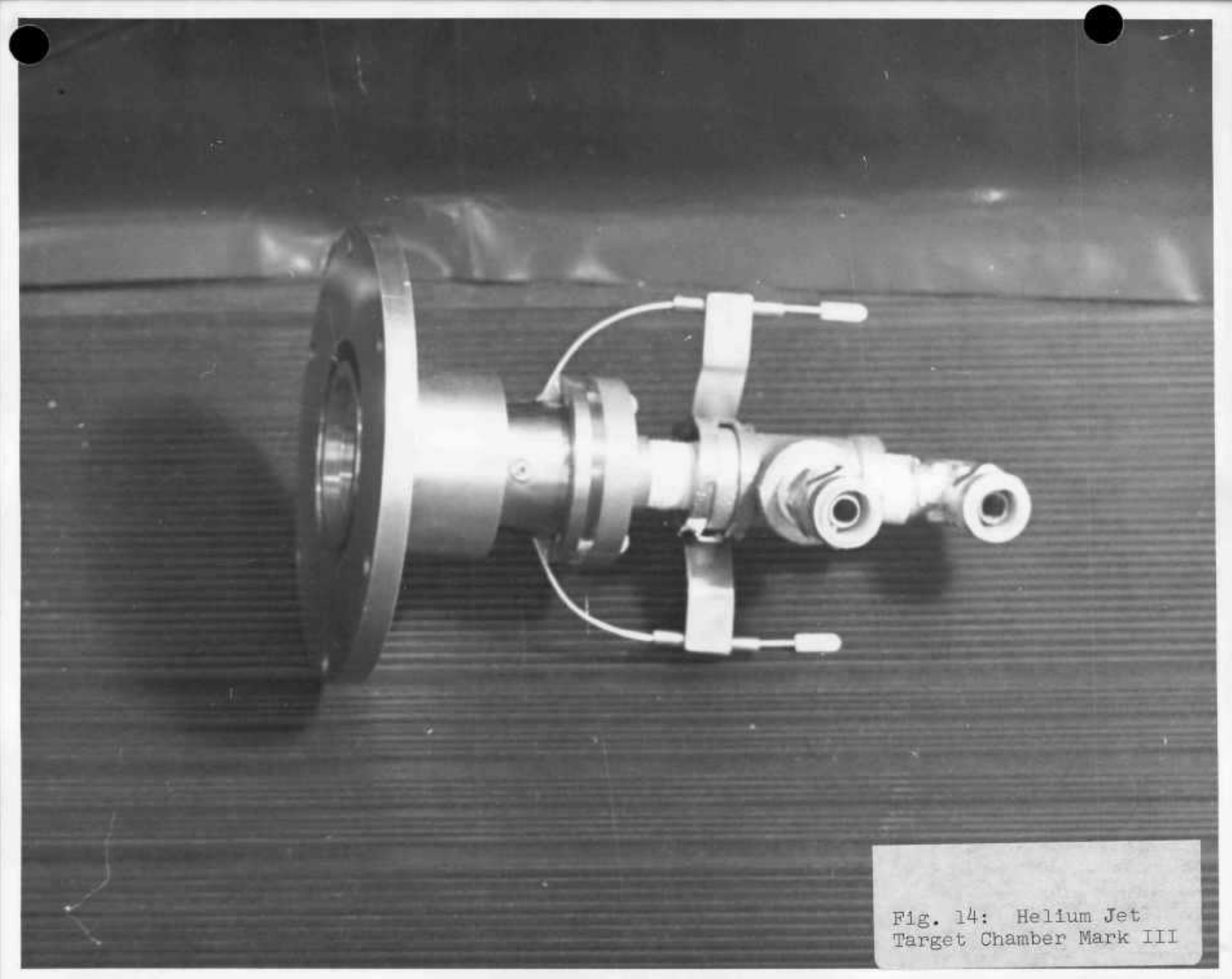




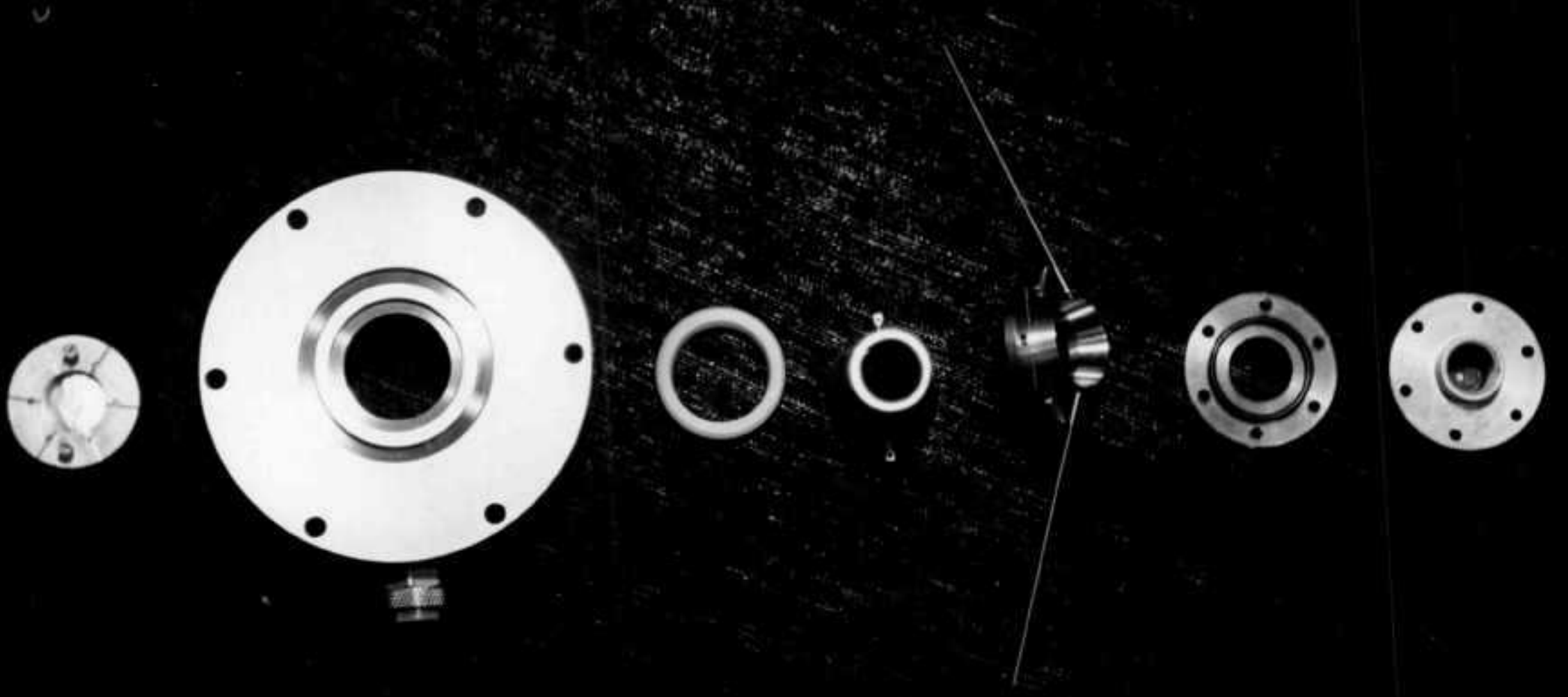

F1g. 15: Heltum Jet

Target Chamber Mark III Disassembled 


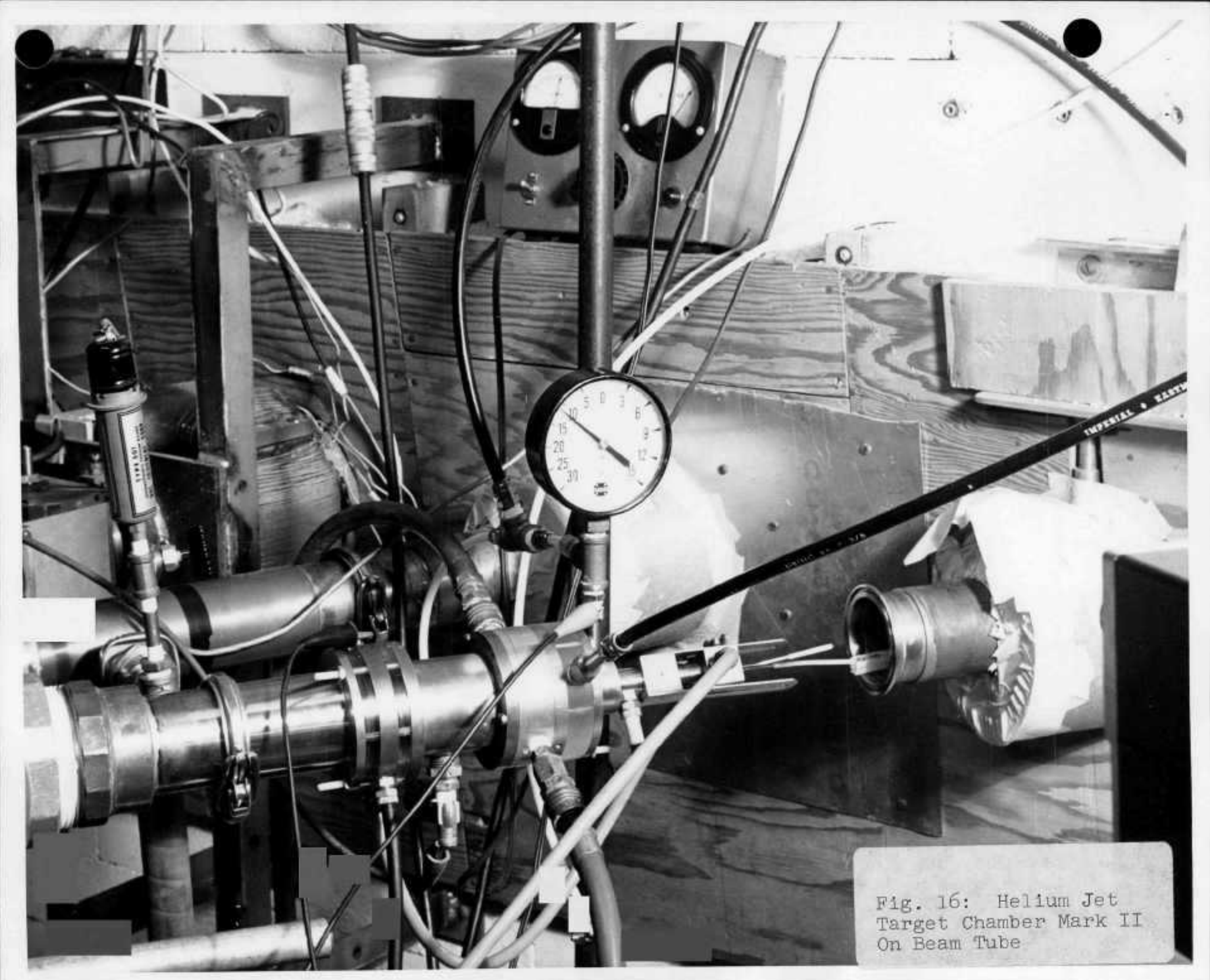




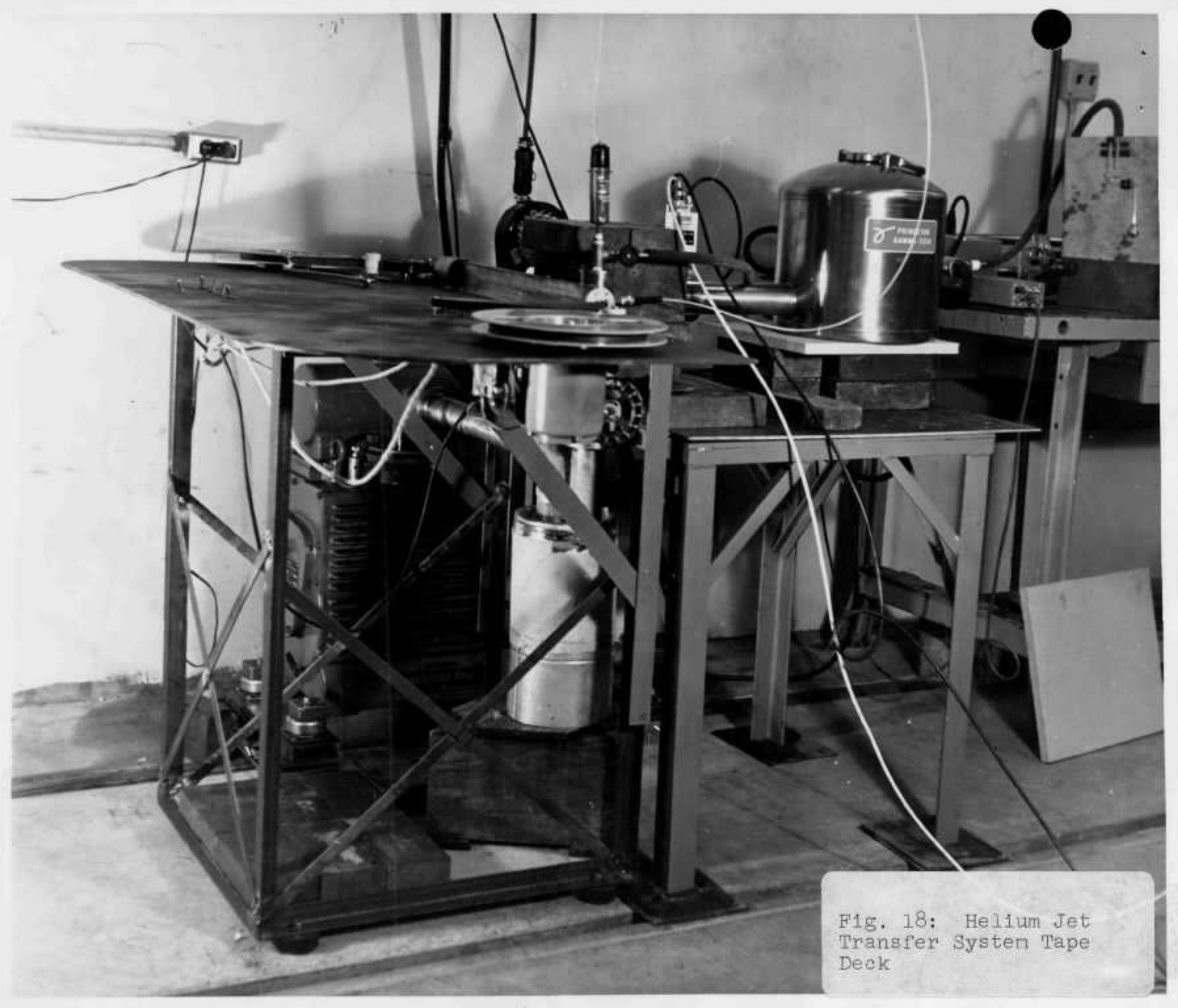




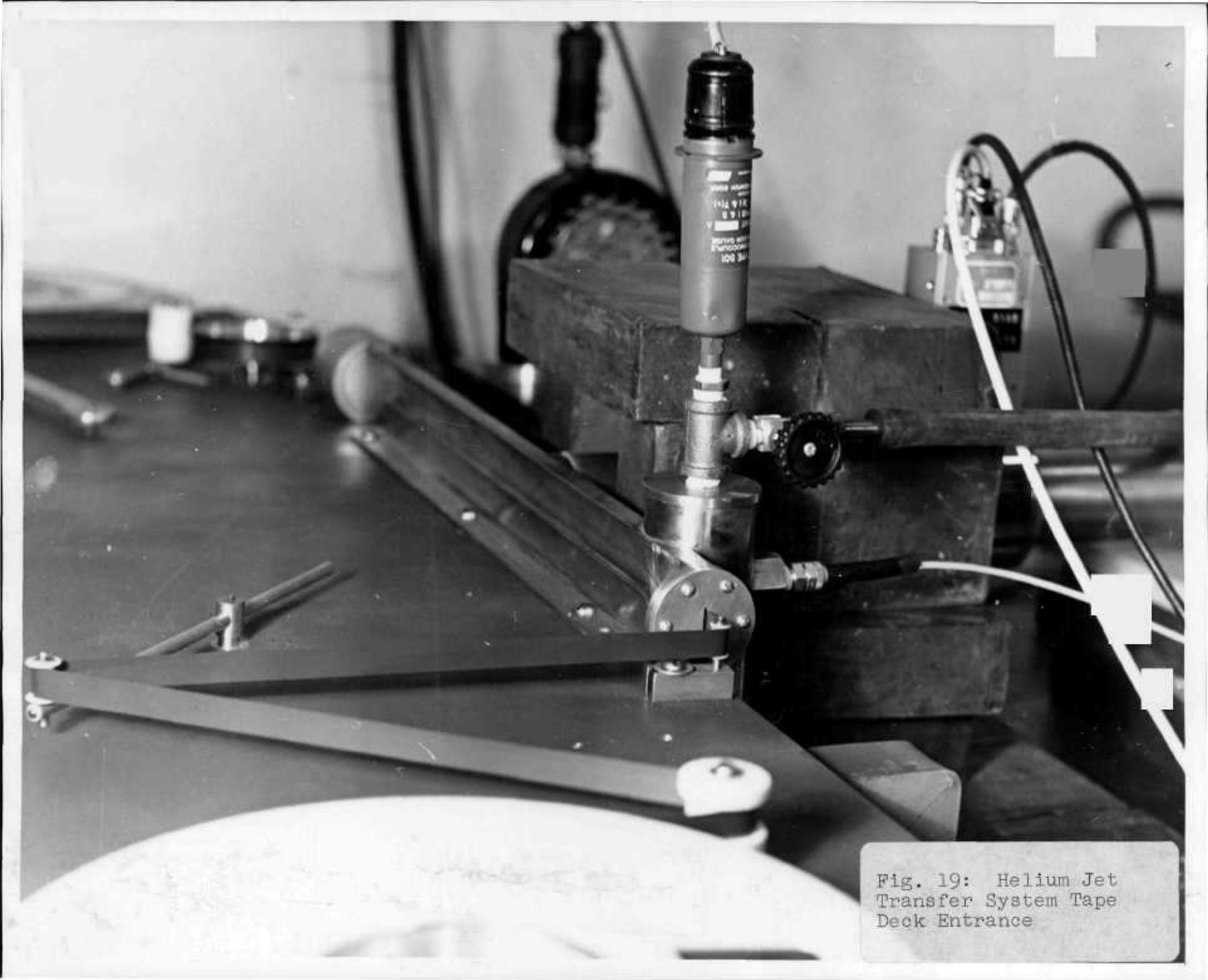




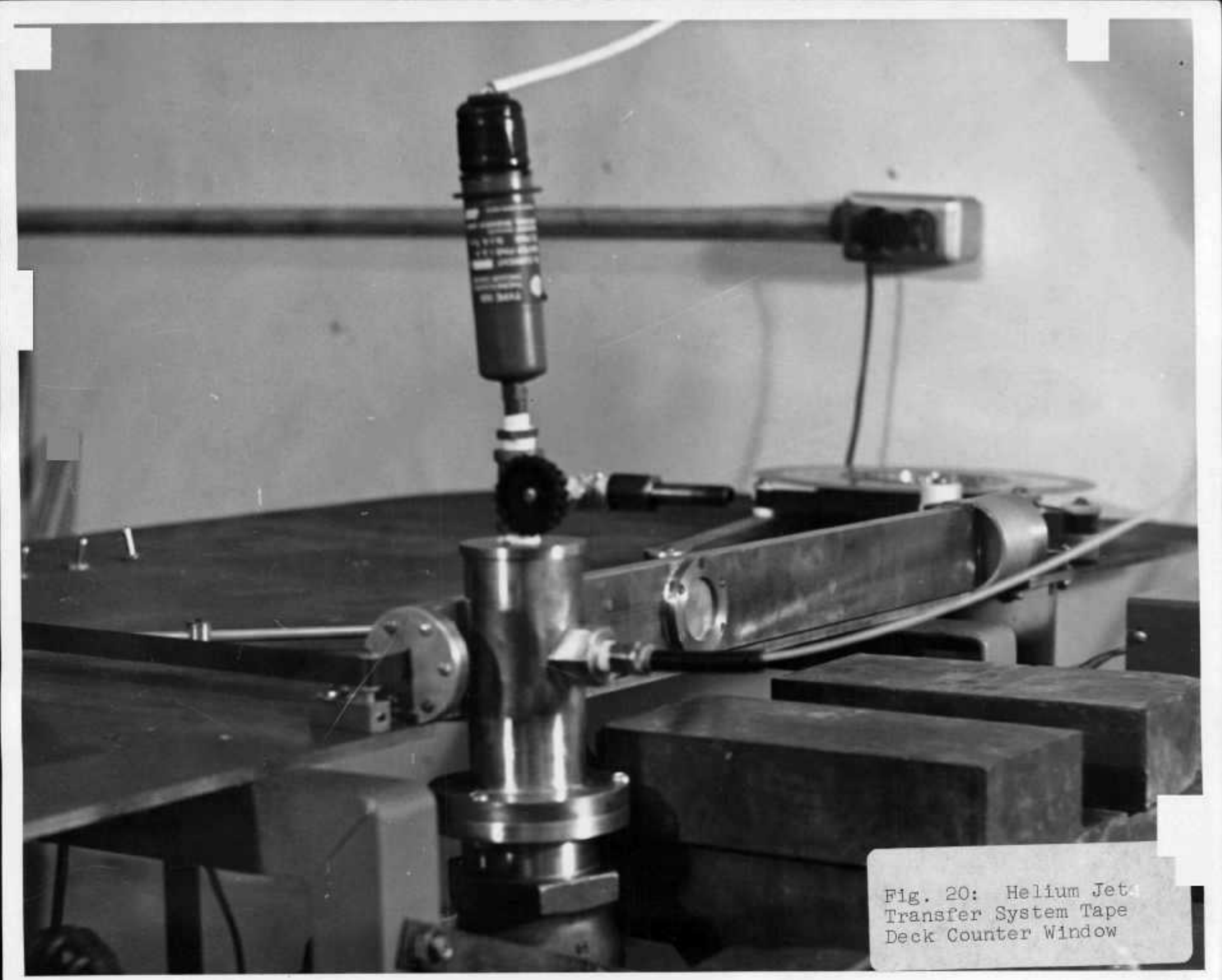

